Purity of key biologically active compounds, 23 and 24, determined by HPLC

\title{
Compound 23
}

$<$ Chromatogram>

mAU
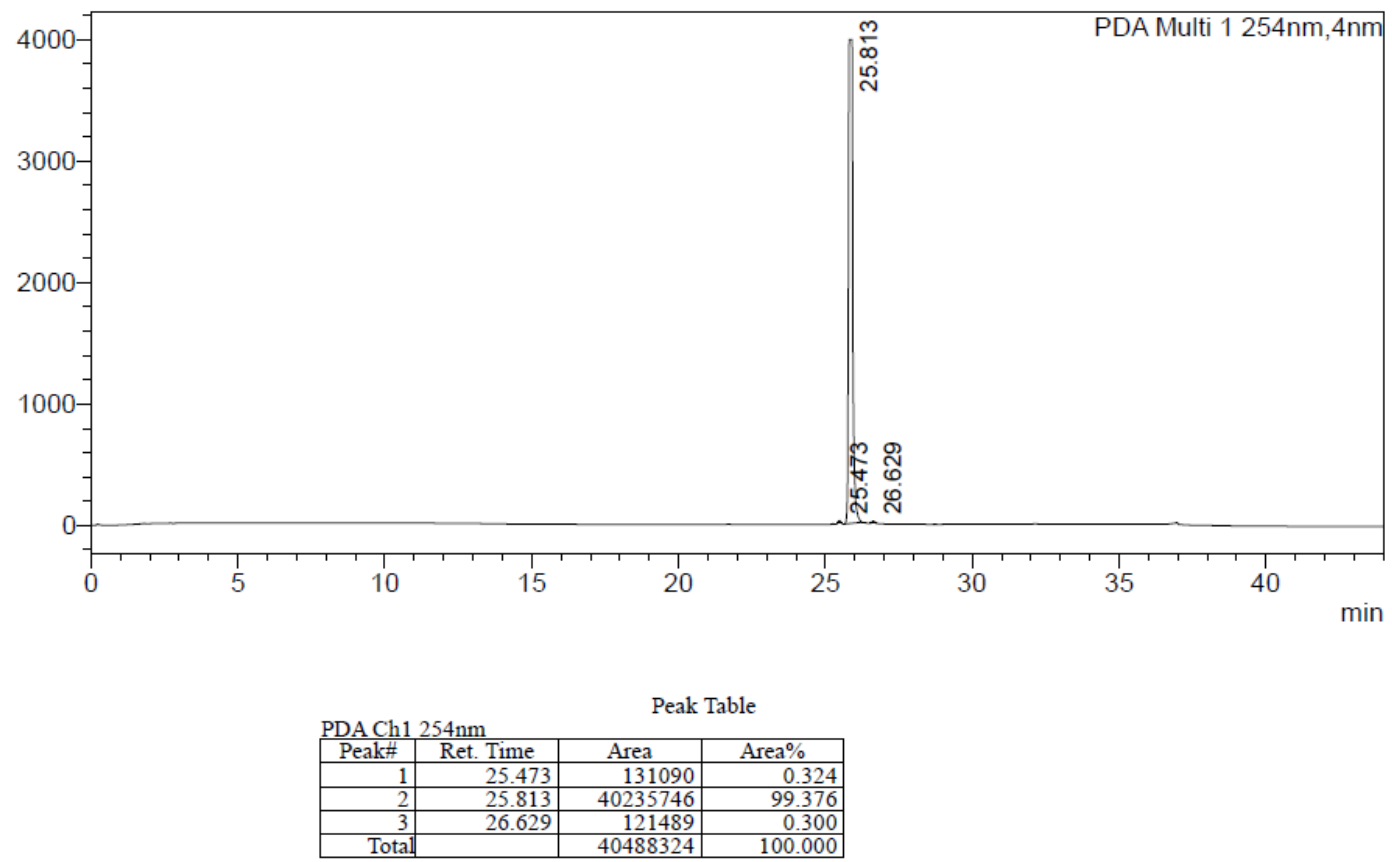

\section{Compound 24}

<Chromatogram>

mAU
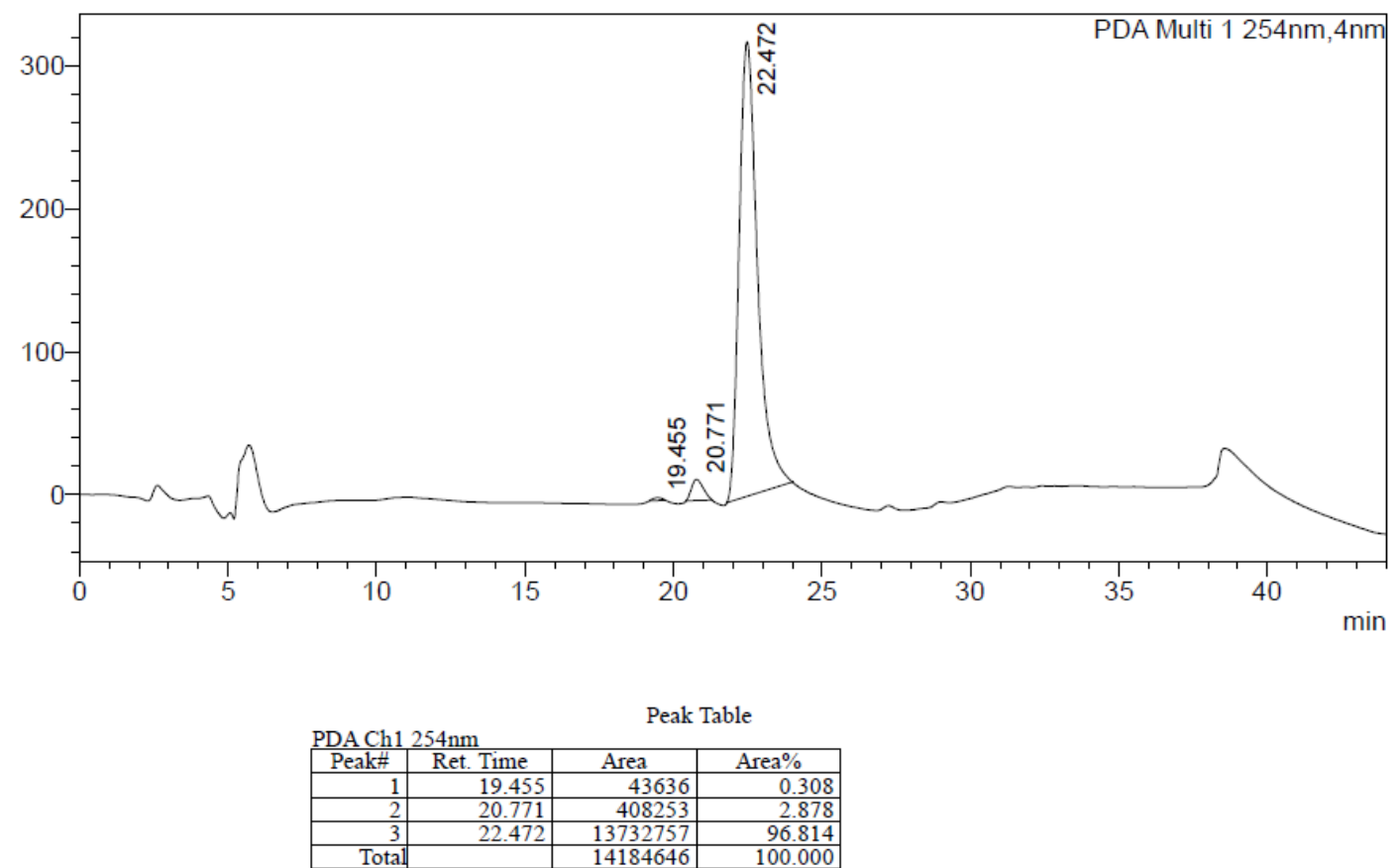